Arab World English Journal (AWEJ) Special Issue on Covid 19 Challenges April 2021

DOI: https://dx.doi.org/10.24093/awej/covid.4

Pp.55-67

\title{
EFL Students Affective Attitudes towards Distance E-Learning Based on Moodle Platform during the Covid-19the Pandemic: Perspectives from Dr. MoulayTahar University of Saida, Algeria
}

\section{Djamel BENADLA}

Department of English Language and Literature

Saida University, Algeria

Corresponding Author:dbenadla@yahoo.com

\section{Mohamed HADJI}

Department of English Language and Literature

Saida University, Algeria

Recived: $3 / 1 / 2021$

Accepted: 4/1/2021

Published: 4/26/2021

\section{Abstract}

The practice of the online learning system in Algeria is novel. However, with the spread of Covid 19, Algerian universities have been compelled to undertake remote and digital teaching. The University of Dr. MoulayTahar in Saida has arbitrarily hastened in implementing E-learning as an alternative teaching measure to maintain both positive educational outcomes and keep students safe and healthy. This research purports to examine how the University of Dr. MoulayTahar in Saida has used Moodle platform to facilitate the teaching process during the Covid 19. This paper, therefore, stresses the issues of distance e-learning that challenge both teachers and students alike. The researchers attempt to answer the following question: What are the affective attitudes of EFL students towards distance learning assisted with Moodle Platform during the Coronavirus? To supply an adequate answer to the raised question, the researchers have selected a sample of 157 participants. The researchers collected data through a questionnaire and delivered copies to the participants. The findings revealed that both the teachers and the learners were not well prepared for an online learning experience. That there are more disadvantages than advantages. The results of the research conveyed that the technical skills, the teachers' lack of experience as well as the social situation of the students have made E. learning a complex process. The analysis also revealed that Master students have negative attitudes towards e-learning, and they would prefer face-to-face interaction in the classroom and handouts more than virtual learning.

Keywords: Covid-19 pandemic, distance - learning, Dr. MoulayTahar University, e-learning, Moodle platform, EFL students' attitudes

Cite as: BENADLA, D., \&HADJI, M. (2021). EFL Students Affective Attitudes towards Distance E-Learning Based on Moodle Platform during the Covid-19the Pandemic: Perspectives from Dr. MoulayTahar University of Saida, Algeria. Arab World English Journal (AWEJ) Special Issue on Covid 19 Challenges (1). 55-67. DOI: https://dx.doi.org/10.24093/awej/covid.4 
Arab World English Journal (AWEJ) Special Issue on Covid 19 Challenges April 2021

\section{Introduction}

The tremendous and rapid changes in communication and technology in the digital age, have universally introduced the notion of distance education, rendering its practices a globally no returning point and thanks to ever its increasing accessibility, openness, and flexibility (Harasim, 2000). Algerian universities, akin to all the universities of the world influenced by school and university closure, have opted for distance education and coined the concept of e-learning - a digital platform called "Moodle"- alternative method to face the Pandemic of the Coronavirus. The idea of distance education is introduced to assist ambitious learners who cannot attend regular full-time classes to fulfill their educational aspirations. It is characterized by its adaptability, flexibility, and students' learning-centeredness, therefore, improving students' interactions via synchronous and asynchronous technological implements (Dhawan, 2020). However, during the last few months, the whole world educational system has dramatically been changed due to the Covid19, which resulted in unpremeditatedly abrupt and unprecedented schools and universities lockdown (Ali, 2020).

To face the phenomenon of being away from regular class courses, schools and universities have taken colossal and audacious measures to face this challenging turmoil. Teachers are then obliged to adapt their teaching methods opting for internet-based learning to preserve a certain amount of educational continuity and maintain life at schools and universities (Abou El-Seoud, Taj-Eddin, Seddiek, El-Khouly\&Nossier 2014). Some developed countries are more or less technologically well-equipped and supported with well-trained staff to face the situation. However, many countries - in a state of unsuspected confusing haste - are obliged to adapt their teaching and learning in due time with insufficient training and mediocre preparation. Universities and institutions use multiple methods in online learning, such as remote and digital platforms. Algerian schools and universities have adopted various designs for distance education, like online lectures, distance drills and exercises, virtual tutorials, video conferences, group works, and assessments. The University of Dr. MoulayTahar, Saida, like all Algeria universities, has shifted to the Moodle-based online learning Platform where teachers deliver curricula, courses, syllabi, lectures, lessons, and activities. Nevertheless, another issue has emerged among EFL students, especially in the ELT department.

There has been an echo of dissatisfaction with distant teaching assisted with Moodle Platform, which manifests itself in the attitudes of the target students and their resulting grades. Both teachers and students have detected many obstacles in the learning process when using these e-learning platforms. Students were often featured as being reluctant due to their decreased motivation. They delayed feedback cause of the unavailability of their teachers at moments of learning processes or simply because of their growing weariness and feeling of isolation (Yusuf \&Banawi 2013).Besides, the researchers believe that these issues might be qualified as being more notable owing to the inexperienced teachers in using E-learning and due to the great haste during which they had to adapt their teaching style to the new circumstances.

Increasingly, while implementing this rapid virtualization process students, have crashed into many tedious challenges. Among these challenges are the enormous amounts of imbalanced online courses, which could undoubtedly jeopardize the health of the students, both physical and emotional, while spending successively long hours in front of a screen. Besides, even if these courses were available online, the educational institutions and universities have not considered 
that not all students are lucky enough to have computers, proper instruments, and access to the Internet. The lack of accessibility, the shortage of devices, and the increasing weariness caused by the lack of communication and interaction with teachers and peers would undoubtedly affect the students learning process and academic achievement. (Aboagye, Yawson, \&Appiah, 2020). This current perplexing matter qualifies the present investigation to be more than primordial to undertake attemptable measures to determine the soft spots of our digital weaknesses and mitigate the impact of immediate schooling closures. By so doing, experience and knowledge about teaching in the online environment are more than fundamental to positively strengthen this field of virtualization process learning and scaffold learning accordingly. The researchers attempt to answer the following questions: What are the effective attitudes of EFL students towards distance learning assisted with Moodle Platform during the Coronavirus? To what extent are students capable of assimilating the information used in online learning platforms?

\section{Literature Review}

In recent years, the treatment of distance or virtual learning throughout the universities of the world is generally marred with conceptual vagueness. It has become one of those fashionable and political catchwords often invoked by rare properly defined or submitted to scrutiny. While embraced as an inevitable learning strategy to increase interactivity and maintain education continuity, especially during the pandemic Coronavirus, distance learning has also become the focus of some criticism. Therefore, to attune the learners' needs and reinforce their teaching and learning requirements, colossal investments have been launched on E-learning systems and devices (Popovici\&Mironov, 2015). The difficulty of bringing the concept of E-learning under a single definitional umbrella has raised diverse controversy. E-learning, however, would simply mean the incorporation of all educational activities performed by a group of individuals working online or offline via networked or standalone computers and other electronic devices (Horton, 2006). Horton defines E-learning as "the use of information and computer technologies to create learning experiences" (p.1).Similarly, Rosenberg (2001)defines E-learning or electronic learning as a concept that uses Internet technologies to provide a wide array of solutions that enhances and transforms knowledge and performance. Teachers and lecturers use various electronic devices to meet the learners' needs.

Subsequently, the integration of distance learning in Algerian universities dates back to 2006, when Algeria collaborates with "Thompson" and "Microsoft", has launched an e-learning system. Information and Communication Technologies (ICT) were introduced in higher education as a teaching tool to facilitate access to knowledge. Moreover, its courses purport to familiarize learners with basic concepts of communication and networking. It aimed at offering learners new ways of teaching and learning using distance teaching techniques. By so doing, teachers and lecturers have designed 4.000 courses and lectures to teach ICTs and communication skills (Guemide\&Benachaiba, 2012). Guemide and Benachaiba strongly believe that ICTs refer to "forms of technologies that are used to transmit, store, create, share or exchange information" (p.4).However, the e-learning strategy delivered by Djaweb, Guemide, and Benachaiba have noticed could not bring any advantage to the teachers aspiring to integrate ICTs and e-learning in their professional careers. They are devoid of any specific programs.

Being incredibly aware of the importance of E-learning enhancing knowledge and sharing information, and improving communication at a broader scale has compelled the 
Arab World English Journal (AWEJ) Special Issue on Covid 19 Challenges April 2021

EFL Students Affective Attitudes towards Distance E-Learning

BENADLA \& HADJI

Algerian government to consider investing in the educational field. Accordingly, academic research has received considerable support from the Algerian government to increase lifelong learning opportunities and institutional autonomy while producing learning outcomes more attuned to the learners' needs. However, despite the Algerian policy-makers' deliberate focus on the significance of research and continuous learning, Algerian universities are still providing students with mediocre research skills (UNISCO, 2004). Two great reasons are identified: The first refers to the inaptitude of the trainers to handle the new technologies and adopt adequate pedagogies, whereas the second reason refersto the question of the readiness of the Algerian learners and their ability to adopt new learning strategies involving the use of computers and the Internet (Djoudi, 2007).

Under the pressure of the unusual condition engendered by the Pandemic Coronavirus, the Algerian policymakers, instructors, and educational teachers have made haste to advertise for this new strategy of distance learning. Many studies are conducted, and an avalanche of articles are written to shed light on this new concept of teaching by inflicting so many investigations on the advantages and disadvantages of e-learning during the Pandemic. Thus, Zermane and Aitouche(2020), for instance, have investigated the positive sides of engineering education and online courses during the Pandemic of Covid-19. For that objective, Zermane and Aitouche claimed that "in the last decade, over 13,000 agreements between industry and academic institutions have been signed, resulting in the training of 650,000 new workers" (p.165). Another research SouadGuessar, from the University of Bechar, has also investigated the impact of Covid-19 on the Algerian University. Guesser (2020)has put under scrutiny the effect of the pandemic on the conduct of lessons at the Algerian universities. Ghounane(2020), another researcher from the University of Dr. MoulayTaharSaida, emphasizes the importance of Moodle and other social networks in distance learning.

Nevertheless, no paper,as mentioned above,has focused on the learners' attitudes towards these electronic platforms. Just minor studies that focus on the learners' feedback towards lecture assimilation and course interaction via distance learning are made. Nobody has anticipated the significant disruption in the educational system caused by a pandemic that weirdly baffled the teachers and the students alike. Mainly when both are unfamiliar with online learning platforms or are compelled to change rapidly from traditional learning to less technology-savvy online learning. Subsequently, the objective of this present paper is to highlight the reasons behind the delay or the reluctance of the universities in Algeria in embracing the e-learning experience despite the considerable efforts devoted by the Ministry of Higher Education to ensure its success. By so doing, experience and knowledge about teaching in the online environment are more than fundamental to positively strengthen this field of virtualization process leaning and scaffold learning accordingly. The present researchers attempt to facilitate the E-learning process by supplying information on the adequate and usefulness of specific strategies concerning course delivery, time completing tasks and projects, content course balance andstudent's grievances needs, and preferences for teaching techniques.

\section{Methods}

To conduct this research, the researchers have deliberately focused on the analysis of students' perception concerning online learning, their ability to digest and assimilate information, and the availability and use of E-learning platforms. Thus, the researchers have 
devised an online survey composed of an elaborated questionnaire to gather information and collect feedback from respondent students concerned with the lockdown during the second semester. The respondents belong to two different program options of master studies (MA) in Literature and Civilization and didactics. Due to the unprecedented schooling, closing decisions were taken abruptly by the Algerian government by the mid of March 2019 to avoid the rapid virus proliferation among students. The researchers have delivered the survey to the learners via private e-mails and other social media networks such as Facebook and Twitter. The data were collected from 157 Master students at the ELT Department.

\section{Participants}

The study population was selected in a non-probabilistic way. It comprised 157 students from the department of English Language and Literature Faculty of Literature, Foreign Languages, and the Arts, University of Dr. MoulayTahar, Saida, Algeria. The sample consists of 76 participants from first-year Master's students in both streams: Literature and Civilization and Didactics, and 81 students from both streams Master second year. The majority of respondents are female, primarily up to 24 years old, from urban areas. However, 29 (18.47\%) of the students were male, and 128 female $(81.52 \%), 84(53.50 \%)$ were from a rural area, $73(46.19 \%)$ from an urban area (Table one).

Table 1.Socio-demographic characteristic of respondents

\begin{tabular}{|l|l|l|l|}
\hline Variables & Category & Count & Percentage\% \\
\hline Gender & Female & 128 & 81.52 \\
& Male & 29 & 18.47 \\
\hline Degree & Master I & 76 & 48.7 \\
& Master II & 81 & 51.59 \\
\hline Age & $20-22$ & 129 & 82.16 \\
& $22-25$ & 21 & 13.37 \\
& Over 25 & 7 & 04.60 \\
\hline ResidentialEnvironment & Rural & 84 & 53.50 \\
& Urban & 73 & 46.19 \\
\hline
\end{tabular}

\section{Research Procedures}

The researchers have sent the questionnaire during the second semester of the academic year 2019-2020. The study participants were informed at the beginning of the questionnaire about the purpose and the objective of the survey. The Participants immediately responded positively to the participation in the study. The participants were allotted up to 20 minutes to answer the questionnaire. The researchers have focused on the learners' attitudes towards elearning sustained by Moodle platform. The questions were designed to get overall feedback from the learners' behalf, their motivations and interest in distance learning in general, and Moodle platform used by Dr. MoulayTahar University of Saida. See a sample of the questions in appendix A.

\section{Research Instruments}

The elaborated questionnaire involved items related to the two raised research questions. Accordingly, the researchers unhesitatingly incorporated the elements corresponding to the students' attitudes towards integrating Internet tools in language learning activities. To put stress on the first question, for example, the researchers have included the following items: the 
attitudes of the studentsvis a vis frequency of technical problems in virtualization learning. In this case, four elements related to the connection to the Moodle platform such as sound clarity, delayed message viewing, loss of signal or no signal at all, surrender with the schedule, balanced teaching style, assigning tasks to students compared to face-to-face learning, obstacles encountered in the E-learning process were strongly emphasized.To keep with the same pace concerning the students' attitudes towards the use of E-learning supported by Moodle platform as an exclusive way to teaching, the researchers have used the following items: opinion towards online learning (5-point Likert scale, where $1=$ not at all satisfied, $5=$ very satisfied), sentiment towards the students' assimilation andinformation processing on the different online answers were recorded: (5-point Likert scale where $1=$ less complex, $5=$ more difficult).

Concerning the second research question, the researchers have included the following items: opinion towards the use of the Moodle platform, assimilation of information and online learning compared to face to face learning, processing information, the type of course that facilitates information processing, preference for interaction with teachers during courses/seminars, the difficulty regarding the presentation of the seminar projects online, opinion towards online learning, appreciation for future learning in higher education (online, face to face, or a combination of both). However, for purely descriptive purposes, the last part of the questionnaire was devoted to a series of socio-demographic variables such as gender, background, degree level, a field of study. The researchers have used the quantitative method to analyze the answers ofthe open items by classifying them into various categories which refer to the central conditions for successful online learning, especially teachers' and students' technical aptitudes, technical needs, teaching method, and online students/teachers' interaction. The researchers have analyzed the data by using descriptive statistics based on percentages.

\section{Results}

It should be highlighted, however, in the information displayed in table one that the University of Dr. MoulayTahar, teachers and students alike were not well prepared for the abrupt shift to online learning and teaching process despite the enormous efforts of the Algerian government. Unfortunately, this is not the case with Algeria alone. Kirkwood (2009) observed that many countries had spent vast sums of money on infrastructure and educational institutions; however, they still do not harvest the aspired results in developing learning communities.Nevertheless, despite their non-updated means and infrastructure shortage, lecturers attempted to find strategies and create suitable methods to adapt and meet the new challenges. Thus, most teachers have moved to virtual classrooms, all thanks to tools such as Moodle. There are some still struggling to get online. Indeed, the shift from a traditional knowledge transmission method to an online learning approach takes place in unexpected automatic way (Armellini\& Jones, 2008; Swan, 2010). This shift however, does not occur automatically. It is discovered that some lectures may require great endeavors, training, and new teaching models (Burge \&Polec, 2008).

Often both the respondent students and lecturers have complained about disruption in the Internet connectivity or trouble with WIFI due to the lack of the technical capacity to deliver optimal for online learning conditions. $71.33 \%$ of the respondents complained that they frequently and very frequently encountered technical problems with the platforms provided by 
Arab World English Journal (AWEJ) Special Issue on Covid 19 Challenges April 2021

the university, without forgetting to mention the great panic of some teachers over the prospect of teaching students over the digital platforms (Iwai, 2020).

Strange enough, some lectures attempted to find other alternative means by using their e-mails and Facebook application; but this has generated stress among some students because there was no clear interaction between the students, and their teachers and teaching were merely transformed into purely sending and receiving messages with a few quick keystrokes $75.23 \%$ of students mentioned this aspect). Thus, most teachers let "the Trojan-like mouse" into their pedagogical activities without noticing that it will demand them to reconsider their use of hardware and software in their teaching process. What they are doing, Abrioux(2001)noticed, is just enhancing "old models of distance education by taking advantage of the e-learning environment" (p.1). This would suggest that we have failed in bringing about this shift in the teaching process.

The problem of accessibility to the Moodle platform is another burden to be added to this new shift of pedagogical approach. Both have complained of poor and connection troubles, especially when the number of students connected was high. Besides, students' lack of adequate technologies for participating in online learning has overlapped with these issues (lack of laptops/computers, the mobile connection that partially offers access to resources provided by Moodle platform, especially those who live on the campus), $15.15 \%$ of respondents mentioned these aspects(See table two on appendix B).

The researchers also observed that most teachers lack the necessary technical skills to be able to either adapt their teaching style or to appropriately interact with students in the online environment assuring high standards of the teaching process. They have not realized yet that the pedagogy in online learning is quite different from face-to-face teaching. They are not well experienced in designing activities suitable for distance learning. $19.43 \%$ of respondents remarked the teachers' incompetence in distance mediation education to accomplish their teaching task. Some would even resist using e-learning because they find it difficult (Collis \&Moonen, 2008). When asked about their readiness about the use of e-learning, twenty-seven teachers of 38 in the English Departmentshowed negative attitudes.

The research results also revealed that $35.2 \%$ of teachers were unwilling to improve their teaching skills in the online environment. Furthermore, $30 \%$ of students mentioned that the main issue was the teachers' lack of adaptation to the online environment. The issue undoubtedly would negatively affect their ability to assimilate and understand the subjects taught during the courses (Table three).

Table 3.Frequency distribution of indicators related to students' perception of the use of the E-learning platform

\begin{tabular}{|l|l|l|}
\hline Variables & Category & Percentage \% \\
\hline Previousexperience & $\begin{array}{l}\text { Previous use of the E-learning Moodle } \\
\text { platform }\end{array}$ & 5.2 \\
\hline $\begin{array}{l}\text { The usefulness of the E-learning } \\
\text { platform }\end{array}$ & $\begin{array}{l}\text { People who considered the usefulness } \\
\text { of the Moodle Platform as a tool of } \\
\text { collaborative learning. }\end{array}$ & 36.18 \\
\hline Intention to use & Preference for the E-learning platform & 42.76 \\
\hline
\end{tabular}


Arab World English Journal (AWEJ) Special Issue on Covid 19 Challenges April 2021

Based on the results displayed intable three, it is noticed that just a minimal number of teachers and students alike have prerequisite knowledge of e-learning Moodle platform usage $5.2 \%$,however,the majority have great intentions, preference and devotes for e-learning. The variancechoice for the Moodle e-learning platform is quite wide, 42.76\%. For the teaching process to efficiently occur online,policymakers, educators, and students should reconsider the excellent intention and ambitions for distance learning appropriately. They should realize that in the domain of teaching and learning across different environments in the digital age there isalways some work left over to perform. The last part of the survey in this research was devoted to the students' ability to assimilate and learn in the online learning context (See Table four on Appendix C).

\section{Discussion}

Most students affirmed that the lack of interaction with their teachers had hurt their ability to assimilate and understand the subjects taught during the courses. Just a few limited numbers of teachers were fortunate enough to deliver their lectures through video conferences $2.2 \%$. Although most of the correlated variants have demonstrated positive attitudes towards Elearning, the students' opinions towards online courses appeared to be quite distinctive and divergent. $50.5 \%$ of the respondents found it difficult to process information in an online teaching environment compared to $20.5 \%$ who qualified it as being accessible in aregular classroom. The issue, in turn, undoubtedly impedes the students' concentration and stimulus and affects their response. Moreover, students complained about the considerable amount of lectures displayed on the Moodle platform compared to the short lifespan to digest and process these courses. To make it more explicit, there is an abundance of information and a considerable quantity of knowledge on the platform concerning the time limits and the means students have to process them. Processing informationwould require the selection of suitable material, analysis, synthesis, and experiential insights processes which would demand transcending both time and space.

Consequently, learners became very distracted and might lose focus and even motivation. For better assimilation of information, it is advisable to balance the number of course and valuable tasks and to assign students a decent number of practical studies for them to avoid spending too many hours in front of the computer. Thus, this implies certain creative thinking in designing tasks that stimulate collaborative learning. Assimilation of information also requires technical skills to create and implement programs to improve interaction among students. Furthermore, teachers must provide feedback on the tasks solved by students quickly. It is of utmost importance for teachers to remain constant reminders to students, particularly those reluctant ones who keep procrastinating things assignments and, or deadlines. It is fundamentally crucial that teachers be available and open to students' needs to increase their engagement and involvement in the educational process (which is lower in the online environment).

Thus, the respondents' opinions regarding the use of the virtual environment for learning are divided. Some of them $(27.8 \%)$ consider it an appropriate setting for learning. Some believe it is not very convenient $(38.5 \%)$, and a third is undecided $(33.7 \%)$. The same thing happens when it comes to satisfaction towards their online learning experience: $29.1 \%$ being delighted and satisfied by the E-learning process, $25.9 \%$ were undecided, and $45 \%$ were dissatisfied. 
No doubt E-learning may have enormous advantages, but its downsides are ignored too, especially in Algeria. Information-processing depends on technology such as the Internet and computers, to which students may not have access. Often interruptions and other system errors may appear during courses. The variants in table oneshow that most of the students are from rural areas (53.50\%), which means that the challenge of internet connectivity is even worse, particularly for girl students who live oncampus (81.52\%). Even if Internet connectivity is partially solved, not all students have computers and smartphones to get connected. There is, therefore, a significant gap between those from privileged and disadvantaged backgrounds. It is high time policymakers and educators thought deeply about this obstacle to water down the drawbacks in this new online teaching environment to create justice and educational opportunities among all learners. Besides, the lecturers must be aware of their learners' profiles when designing their online courses. They should address the learners' differences appropriately and effectively (Beetham\& Sharpe, 2019).

Subsequently, the present research demonstrates that the success of the digitalization applied by the University of Dr. MoulayTaharduring the Pandemic Coronavirus depends enormously on diverse factors. If the teachers are not well trained in using technology, do not improve their teaching style, interact with their students, use different strategies to persuade them to devote more time for studies, diversify their technological learning tools, so the project of elearning would be abortive. The study also demonstrates that the students who responded to the proposed questionnaire consider that reliance on exclusive e-learning at the expense of face-toface attendance would harm the learners' assimilation of their processing information. Moreover, some learners descending from poor social backgrounds could not all have access to the Internet. They live in rural areas - "people of the shadow", as policymakers prefer to call them-have neither computers nor smart phones. They are entirely cut from the modern world and find it even more challenging to access to online learning. It is also very exhilaratingthat even though students wish to participate in the online learning process actively, their lack of experience with this type of learning makes them even more anxious.

Furthermore, the learners believe that online learning may even harm their performance due to the poor assimilation of the courses, particularly the hard ones, the respondents have revealed. Besides, the teachers' inability to appropriately adapt their teaching methods shows that the University of Dr. MoulayTahar is not yet ready to integrate E-learning in the teaching and learning processes.

\section{Conclusion}

The need to include virtual-based learning in Algeria during the crisis of the Coronavirus pandemic has been more than necessary. In a very concise period, the countries all over the globe have made haste to an unprecedented lockdown of schools, universities, and other institutions to prevent the proliferation of the virus among the learners and the staff alike. The world has witnessed significant changes and disruptions in its educational system, transforming indoors and homes into schools, institutions, and universities. Thanks to digital technology, educators and lecturers were forced to switch to E-learning platforms. Algeria, like many other countries, has opted for technology-based and distance learning. Algerian universities and the University of Dr. MoulayTahar, Saida, is one among them has adopted the Moodle platform providing students 
Arab World English Journal (AWEJ) Special Issue on Covid 19 Challenges April 2021

with online course contents. It is an E-learning project designed to help teachers construct efficient and effective communities for authentic learning (Singh, O’Donoghue\&Worton, 2005).

Nevertheless, after analyzing the results obtained in this study, the researchers can draw the following conclusions on Moodle platform adopted by the university. So despite its variety of positive features such as efficiency in terms of cost, friendly interface, easy information transfer, psychological comfort, and various usages lurk several challenges. Almost all the respondents have concurred that they have sometimes encountered technical issues and think they process information better in the traditional courses. Besides, multiple factors determine the quality of the educational process in the online environment, among which are: the level of training that teachers' level training in technology use, their interaction with the students, teaching style, collaborative learning, quick feedback, their omnipresence, active learning, and experience in using mediocre technology. Thus some of the advantages aforementioned about E-learning sustained by the Moodle platform dwindle in value, and drawbacks become more outstanding.

Throughout the students' responses to the questions surveyed in the questionnaire, the majority considers that online learning does not have advantageous effects on assimilating and processing information. It is somewhat more challengingto study and be focused online. Besides, teaching online is always hard. Thus students quickly get distracted and lose focus because teachers do not implement the proper strategies to keep their learners focused since they lack experience with this type of learning. Besides, the present study revealed that the process of learning and assimilating information is deficient in the online environment, and this could result in poorer learning outcomes. Respondents frequently reported problems withtechnical materials. As a result, the finding confirms the reasons why students became reluctant and unmotivated. A shortage of infrastructure, notably telephone lines, is also a significant obstacle to increasing Internet access. What makes the matter more badly was the teachers' incapacity to adapt sound methods of teaching, mainly when designing challenging courses. To sum up, the study demonstrates that our university was not ready to implement online teaching and learning environment.

\section{About the Authors}

Djamel BENADLA is a senior lecturer of literature, American Civilization, and critical literary theories at the University of Dr. MoulayTahar in Saida, Algeria. He is a researcher in critical theories, works of literature, and history. His doctoral research addresses identity in ethnic American fiction. He is the author of a series of articles notably about the theatre of the Absurd.https://orcid.org/0000-0001-5781-3633

Mohamed HADJI is an associate professor at the University of Dr. MoulayTahar in Saida, Algeria. He is a very keen to conduct different kinds of scientific research in different fields, especially teaching English for Business and Economics. He is interested in written expression, oral expression, grammar and English for specific purposes. https://orcid.org/0000-0001-97949244 
Arab World English Journal (AWEJ) Special Issue on Covid 19 Challenges April 2021

EFL Students Affective Attitudes towards Distance E-Learning

BENADLA \& HADJI

\section{References}

Aboagye, E., Yawson, J. A., \&Appiah, K. N.(2020). Covid-19 and E-Learning: The Challenges of Students in Tertiary Institutions. Social Education Research, 2(1), 1-8. https://doi.org/10.37256/ser.212021422

Abou El-Seoud, M. S., Taj-Eddin, I. A.T.F., Seddiek, N., El-Khouly, M.M., \&Nossier A. (2014).E-Learning and Students' Motivation: A Research Study on the Effect of E-Learning on Higher Education.International Journal of Emerging Technologies in Learning (iJET), 9(4), 2026https://online-journals.org/index.php/i-jet/article/view/3465.

Abou El-Seoud, S., Seddiek, N., Taj-Eddin, I.A .T. F., Nosseir, A., \& El-Khouly, M. M. (2014). ELearning and Students' Motivation: A Research Study on the Effect of E-Learning on Higher Education. International Journal of Emerging Technologies in Learning, 9(4), 689695.http://dx.doi.org/10.3991/ijet.v9i4.3465

Abrioux, D. A. M. X.(2001). Converting to an online course and program delivery: Global perspectives [Guest Editorial]. International Review of Research in Open and Distributed Learning, I (2). Availableat from http://www.irrodl.org/index.php/irrodl/issue/view/10

Ali, W. (2020). Online and Remote Learning in Higher Education Institutes: A Necessity in light of COVID-19 Pandemic. Higher Education Studies, 10(3), 16-25.

Armellini, A.,\& Jones, S. (2008). Carpe Diem: seizing each day to foster change in e-learning design. Reflecting Education, 4 (1), 17-29.

Beetham, H.\&Sharpe,R. (2019).Pedagogy for a Digital Age Principles and Practices of Design. The UK: Routledge, Tylor and Francis Group

Burge, E. J. \&Polec, J. (2008). Transforming learning and teaching in practice: Where change and consistency interact. In T. Evans T, M. Haughey, \& D. Murphy, (Eds.), International handbook of distance education (pp. 237-258). Bingley, UK: Emerald Group Publishing Ltd.

Collis, B.\&Moonen, J. (2008). Web 2.0 tools and processes in higher education: quality perspectives. Educational Media International, 45 (2), 93106.DOI: $10.1080 / 09523980802107179$

Dhawan, S. (2020). Online Learning: A Panacea in the Time of COVID-19 Crisis. Journal of Educational Technology Systems, 49(1), 5-22. https://doi.org/10.1177/0047239520934018

Djoudi,M. (2007).E-learning experiences in Algerian universities. Available at https:/www.researchgate.net/publication 290559517.

Ghounane, N. (2020). Moodle or social Networks: What Alternative Refuge is Appropriate to Algerian EFL Students to Learn during Covid-19. Arab World English Journal, 11(3), 2141.https://dx.doi.org/10.24093/awej/vol11no3.2

Guemide, B., \&Benachaiba, C. (2012). Exploiting ICT and E-Learning in Teachers' Professional Development in Algeria: The Case of English Secondary School Teachers.Turkish Online Journal of Distance Education-TOJDE, 13(3), 33-49. Available at: https://eric.ed.gov/?id=EJ997805.

Guessar, S. (2020). Algerian University during the Corona Virus Pandemic: COVID-19 - Bechar University as a Sample. European Journal of Education, 3(2), 73-81, Available at: $<$ http://journals.euser.org/index.php/ejed/article/view/4699.

Harasim, L. (2000). Shift happens: Online education as a new paradigm in learning. The Internet and Higher Education, 3(1), 41-61. https://doi.org/10.1016/S1096-7516(00)00032-4

Horton, W. (2006).E-Learning by Design.San Francisco, CA, USA: Pfeiffer:

Iwai, Y. (2020). Online Learning during the COVID-19 Pandemic-Scientific American Blog Network, Springer Nature, Scientific American Blog Network, 2020.Available athttps://blogs.scientificamerican.com/observations/online-learning-during-the-covid-19pandemic/ July 14, 2020.

Kirkwood, A. (2009). E-learning: you don't always get what you hope for. Technology, Pedagogy, and Education, 18 (2), 107-121. DOI: 10.1080/14759390902992576 
Arab World English Journal (AWEJ) Special Issue on Covid 19 Challenges April 2021

EFL Students Affective Attitudes towards Distance E-Learning

BENADLA \& HADJI

Popovici, A., \&Mironov, C. (2015). Students' Perception on Using eLearning Technologies.ProcediaSocial and Behavioral Science, 180, 1514-1519.DOI: 10.1016/j.sbspro.2015.02.300

Rosenberg, M. J. (2001). E-learning: Strategies for Delivering Knowledge in the Digital Age. USA: McGrow-Hill Professional.

Singh, G., O'Donoghue, J., \&Worton, H. (2005).A Study into the Effects Of eLearning On Higher Education.Journal of University Teaching \& Learning Practice, 2(1).Available at: http://ro.uow.edu.au/jutlp/vol2/iss1/3

Swan, K. (2010). Teaching and learning in post-industrial distance education. InM. F. Cleveland-Innes, \& D. R. Garrison, (Eds.), An introduction to distance education: Understanding teaching and learning in a new era (pp. 108-134). New York: Routledge

UNESCO (2004), Restructuring and Differentiation of Patterns of Higher Education in the Arab States: Meeting the Challenges in the Present and the Future, Series.

Yusuf, N., \& Al-Banawi, N. (2013). The Impact of Changing Technology: The Case of E-Learning. Contemporary Issues in Education Research, 6(2), 173-180. DOI: 10.19030/cier.v6i2.7726

Zermane, H., \&Aitouche, S. (2020). Digital Learning with Covid-19 in Algeria.International Journal of 3 D Printing Technology, 4(2), 161-170

\section{Appendices}

Appendix A

Questionnaire about the learners' Attitudes towards e-learning

\begin{tabular}{|l|l|}
\hline Questions & Questions \\
\hline $\begin{array}{l}\text { Q1. What do you think of e-learning implement by } \\
\text { your university? }\end{array}$ & $\begin{array}{l}\text { Q6. Do you expect your teachers to keep using e- } \\
\text { learning in teaching? }\end{array}$ \\
\hline Q2. Do you find E-learning helpful? & $\begin{array}{l}\text { Q7. To what extent you interact with your teachers } \\
\text { and classmates? }\end{array}$ \\
\hline $\begin{array}{l}\text { Q3. Are you all equipped with personal computers } \\
\text { or smartphones? }\end{array}$ & $\begin{array}{l}\text { Q8. What do you prefer, E-learning or face-to-face } \\
\text { learning? }\end{array}$ \\
\hline Q4.Do you all have Internet access? & $\begin{array}{l}\text { Q9.Are you accustomed to using the E-learning } \\
\text { Moodel platform? }\end{array}$ \\
\hline Q5. Do online classes affect your grades? & $\begin{array}{l}\text { Q10.Does online learning enhance your motivation } \\
\text { and interest? }\end{array}$ \\
\hline
\end{tabular}

Appendix B

Frequency distribution of indicators related to the Moodle platform capacity to provide knowledge in the process of exclusively online learning

\begin{tabular}{|c|c|c|}
\hline $\begin{array}{l}\text { Variables } \\
\text { Technical situations and Internet Connectivity }\end{array}$ & \multirow{2}{*}{$\begin{array}{l}\text { Category } \\
\text { The Technical issues while learning online }\end{array}$} & Percentage $\%$ \\
\hline \multirow[t]{4}{*}{ Technical situations and Internet Connectivity } & & 75.23 \\
\hline & $\begin{array}{l}\text { Disruption Internet Connectivity (open } \\
\text { questions) } \\
\text { Internet Speed and Quality (Bad or Slow) }\end{array}$ & $\begin{array}{l}65 \\
\text { Bad } 28.66 \\
\text { Slow } 71.33\end{array}$ \\
\hline & $\begin{array}{l}\text { Use of multiple online platforms (depending } \\
\text { on the teachers' preferences) }\end{array}$ & 00.00 \\
\hline & Lack of studentsadequate technologies & 15.50 \\
\hline Teachers' skills & lack of interest in improving their skills & 19.43 \\
\hline
\end{tabular}


Arab World English Journal (AWEJ) Special Issue on Covid 19 Challenges April 2021

EFL Students Affective Attitudes towards Distance E-Learning

BENADLA \& HADJI

\begin{tabular}{lll}
\hline $\begin{array}{l}\text { Reliance on the existing teaching rules in the } \\
\text { online teaching/learning environment } \\
\text { Teaching Style }\end{array}$ & $\begin{array}{l}\text { Non-compliance with the schedule in the } \\
\text { online environment } \\
\text { Lack of adaptation of teaching style for the } \\
\text { online environment engendering difficulties } \\
\text { of assimilation and understanding. }\end{array}$ & 30.2 \\
& $\begin{array}{l}\text { Unbalanced teaching style(theory versus- } \\
\text { practical tasks) (either just theory or just } \\
\text { practical lessons) }\end{array}$ & 56.5 \\
& $\begin{array}{l}\text { Unbalanced assignment of tasks and time } \\
\text { management }\end{array}$ & 10.15 \\
\hline Interaction withstudent/teacher & $\begin{array}{l}\text { Lack of support from teachers in the learning } \\
\text { process (deficient interaction) }\end{array}$ & 35.2 \\
\hline
\end{tabular}

Appendix C

Variants related to student's ability to assimilate and learn in the online learning context

\begin{tabular}{|c|c|c|}
\hline Variables & Category & Percentage $\%$ \\
\hline Interaction withteachers & Live answer in a video conference & $2.2 \%$ \\
\hline \multirow{3}{*}{$\begin{array}{l}\text { Compared to online teaching, } \\
\text { online information processing is }\end{array}$} & Easier & 20.5 \\
\hline & Harder & 50.5 \\
\hline & The same & 26.8 \\
\hline \multirow{2}{*}{$\begin{array}{l}\text { General opinion towards } \\
\text { learning in the online } \\
\text { environment }\end{array}$} & Dissatisfied & 45 \\
\hline & Neitherdissatisfiednorsatisfied & 25.9 \\
\hline \multirow{4}{*}{$\begin{array}{l}\text { The online environment is } \\
\text { appropriate for learning }\end{array}$} & Very satisfied + satisfied & 29.1 \\
\hline & Very little extent + little extent & 38.5 \\
\hline & Neither little nor great measure & 33.7 \\
\hline & very great extent + great extent & 27.8 \\
\hline \multirow{3}{*}{ Preference for online learning } & Would choose the unfolding online courses & 17.23 \\
\hline & $\begin{array}{l}\text { Would choose the unfolding of face to face } \\
\text { courses }\end{array}$ & 40.1 \\
\hline & $\begin{array}{l}\text { Would choose a combination between the } \\
\text { online and online courses }\end{array}$ & 42.1 \\
\hline
\end{tabular}

